\title{
Cell Aging
}

National Cancer Institute

\section{Source}

National Cancer Institute. Cell Aging. NCI Thesaurus. Code C16394.

Progression of the cell from its inception to the end of its lifespan. 